\title{
Cracks in reproductive health rights: Buffalo City learners' knowledge of abortion legislation
}

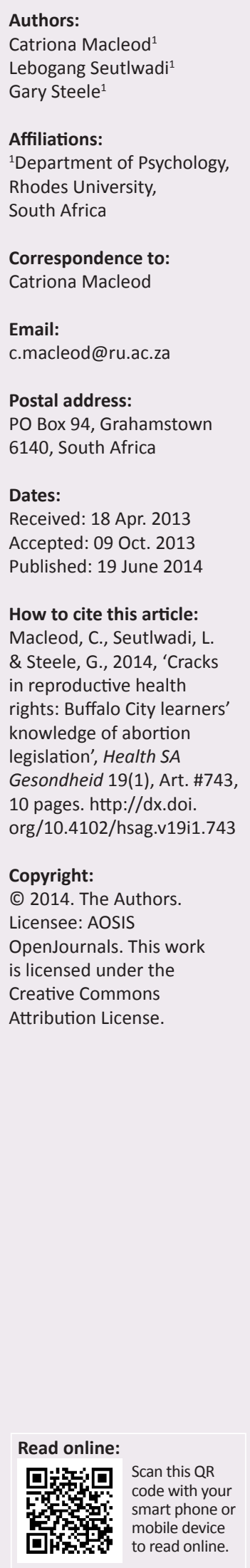

Background: The Choice on Termination of Pregnancy (CTOP) Act legalised abortion on request in South Africa until up to 12 weeks of gestation and thereafter under specified conditions. Within the context of liberal legislation, accurate information is a necessary (although not sufficient) requirement for women to exercise their reproductive rights.

Objectives: This research investigated Grade 11 learners' knowledge of the CTOP Act and its stipulations.

Methods: Survey research was conducted with respondents drawn from a range of schools in Buffalo City, South Africa. Multi-stage sampling was used, namely stratified random sampling of schools and purposive sampling of grades used within schools. The data were collected by means of self-administered questionnaires in group situations.

Results: Results indicate that knowledge of the legal status of abortion, as well as of the various stipulations of the law, was poor. Various misunderstandings were evident, including that spousal approval is required in order for married women to have an abortion. Significant differences between the knowledge of respondents at the various schools were found, with those learners attending schools formerly designated for African learners during Apartheid having the least knowledge.

Conclusion: Given the multiple factors that may serve as barriers to women accessing abortion, it is imperative that at least the most fundamental aspect of reproductive rights, that is, the right to information, is not undermined.

Agtergrond: Die Choice on Termination of Pregnancy Act (CTOP) bewettig aborsie op aanvraag in Suid-Afrika tot en met 12 weke van swangerskap en daarna onder sekere voorwaardes. Binne die konteks van die liberale wetgewing is akkurate inligting 'n noodsaaklike (hoewel nie voldoende nie) vereiste vir vroue om hul reproduktiewe regte uit te oefen.

Doelwitte: Die navorsing het graad 11-leerders se kennis van die CTOP Wet en dié se bepalings geondersoek.

Metodes: Opname-navorsing is gedoen met respondente uit 'n verskeidenheid van skole in Buffalo City, Suid-Afrika. Multi-steekproefneming is gebruik, naamlik gestratifiseerde steekproefneming van skole en doelgerigte steekproefneming van grade in skole. Die data is ingesamel deur middel van self-geadministreerde vraelyste in groep situasies.

Resultate: Die resultate dui daarop dat die kennis van die wetlike status van aborsie, asook van die verskillende bepalings van die Wet, swak was. Verskeie misverstande was duidelik, insluitend dat ' $n$ gade se toestemming nodig is vir getroude vroue se aborsie. Beduidende verskille tussen die kennis van die respondente by die onderskeie skole is gevind, met die swakste kennis onder dié leerders by skole wat voorheen aangewys is vir swart leerders tydens Apartheid.

Slot: Gegewe die verskeie faktore wat as hindernisse tot vroue se toegang tot aborsie kan dien, is dit noodsaaklik dat ten minste die mees basiese aspekte van reproduktiewe regte, naamlik, die reg tot inligting, nie geondermyn word nie.

\section{Introduction}

In the mid-1990s, during the transition to democracy in South Africa, health and human rights activists argued for a liberalisation of abortion legislation based, for the most part, on a combination of women's rights and public health arguments. They hailed the Choice on Termination of Pregnancy (CTOP) Act (No. 92 of 1996) (South Africa 1996; hereafter, 'the Act'), when it was passed, as a significant step in entrenching reproductive health rights (Klugman \& Varkey 2001). Since then, the role of the Act in terms of reducing maternal mortality and morbidity has been 
recognised (Mbele, Snyman \& Pattinson 2007), especially amongst young women (Jewkes, Rees et al. 2005).

\section{Problem statement}

Despite enabling legislation, there is still evidence of women resorting to 'backstreet' abortion (Jewkes, Gumede et al. 2005; Moodley \& Akinsooto 2003). Women presenting to hospitals with incomplete abortions, having accessed abortions outside the designated facilities, cite lack of information on abortion rights under the Act (Jewkes, Gumede et al. ibid) and lack of knowledge of an existing designated facility for legal termination of pregnancy (Moodley \& Akinsooto 2003) as being some of the barriers to accessing abortion services.

In a qualitative study on the perceptions of teenagers regarding the Act, Ratlabala, Makofane and Jali (2007) found that participants felt that young people were uninformed about its stipulations. Other than this, little attention has been paid to teenagers' knowledge about abortion in South African research. Most research on abortion and teenagers conducted after the passing of the Act has concentrated on the experiences of young women who undergo a termination of pregnancy and the views of the general population concerning abortion in relation to teenagers (Macleod 2008).

The importance of knowledge concerning the Act should be seen in the context of national statistics concerning pregnancy and termination of pregnancy amongst teenagers. Makiwane et al. (2006) estimated the age-specific fertility rate (defined as the number of births in a certain year per thousand women in a specific reproductive age group) for 15-19 year-old women to be $66 / 1000$. Rates are higher amongst teenagers living in rural areas, those with less education, African and mixed raced teenagers and older teenagers. Panday et al. (2009) report that learner pregnancies are highest in the Eastern Cape, the province within which this research was conducted.

It is estimated that 15-19 year-old teenagers accounted for $30 \%$ of all termination of pregnancies in 2003 (Panday et al. 2009). Research conducted by Buchmann, Mensah and Pillay (2002) in Soweto calculated the proportion of pregnancies that end in termination of pregnancy (TOP), which has resulted in a more reliable measure of unwanted pregnancies: $23 \%$ of pregnancies carried by 13-16 year-old young women at this site end in abortion; and $14.9 \%$ in the $17-19$ year age range.

It is within this context that this article reports on a survey concerning the knowledge of the Act and its stipulations amongst Grade 11 learners in Buffalo City (a municipal area in the Eastern Cape, South Africa). In the following we outline the stipulations of the Choice on Termination of Pregnancy Act and also outline research on the prevailing knowledge regarding abortion.

\section{Background: Choice on Termination of Pregnancy Act}

After South Africa's first democratic elections in 1994, the Choice on Termination of Pregnancy Act replaced the apartheid- era Abortion and Sterilisation Act (No. 2 of 1975) (South Africa 1975), which granted abortion only under stringent conditions and under which abortion was difficult to obtain. The new Act represented part of the new government's effort to promote safe and accessible reproductive health services. The Act legalises abortion upon request until up to 12 weeks of gestation. After this, up to the 20th week, abortions may be performed if, in the opinion of a medical practitioner, continued pregnancy will pose a threat to the woman's physical or mental health, the foetus is likely to be severely physically or mentally abnormal, the pregnancy resulted from sexual abuse, rape or incest or, finally, if continued pregnancy will significantly affect the woman's social or economic circumstances. After 20 weeks, termination may be performed only if two health practitioners determine that continued pregnancy would endanger the woman's life, result in severe malformation of the foetus, or pose a risk of injury to the foetus.

The Act promotes the provision of non-mandatory counselling before and after an abortion is performed. Importantly, in the context of this research, minors are counselled to notify their parent(s) or guardian(s) but do not require consent from the latter. The law allows for conscientious objection on the part of the providers. However, they are obliged to refer the woman to a willing provider as preventing a lawful termination of pregnancy or obstructing access to a facility that provides abortion is an offence. The CTOP Amendment Act (2008) (South Africa 2008) extended services by allowing any health facility with a 24-hour maternity service to offer first trimester abortion services and any registered nurses who have completed the prescribed TOP training courses to perform first trimester abortions.

\section{Literature: Research on abortion knowledge}

Knowledge concerning the legal status of abortion, of the stipulations contained in the legislation and where services are provided has implications in terms of women accessing termination of pregnancy services (Jewkes, Gumede et al. 2005; Moodley \& Akinsooto 2003). Lack of knowledge erodes women's reproductive rights and their ability to make informed decisions. This erosion is not distributed evenly. For example, in a survey amongst women attending abortion services at eight facilities in three provinces, Cooper et al. (2005) found that four times the proportion of rural women compared with urban women delayed seeking an abortion because of insufficient information on abortion and abortion services.

Whilst the knowledge of those presenting late for abortion services or presenting with incomplete abortions provides insight into how lack of knowledge impacts on women's ability to exercise their reproductive rights, understanding the extent and nature of knowledge concerning abortion in the general population is also required. The 1998 South African Demographic and Health Survey (SADHS) contained a question relating to knowledge of abortion. At the time, two years after the implementation of the Act, $53 \%$ of women 
knew about the law. Knowledge was poorest amongst teenagers, those in the 45-49 year age range, women living in rural areas, those with less education and black women (Department of Health 2002). The 2003 SADHS did not include a similar question.

Two substantive surveys have been conducted more recently, although for each the sampled population is specific. Morroni, Myer and Tibazarwa (2006) conducted a cross-sectional study of 831 women presenting at 26 public health clinics in an urban and a rural health district in the Western Cape. Thirty-two percent of the women did not know that abortion is legal in South Africa, with women presenting at rural clinics being significantly more likely to not know the legal status of abortion than women presenting at urban clinics. Of those who knew that abortion is legal, just under half did not know about the gestation restrictions. Interestingly age, level of education and employment status were not associated with knowledge.

Mwaba and Naidoo (2006) conducted a survey with undergraduate psychology students from a South African university, a population that would be expected to be relatively well informed. Results showed that $19 \%$ of the male students and $16 \%$ of the female students believed that abortion was illegal in South Africa. In terms of the various stipulations of the legislation, $28 \%$ of the male students and $23 \%$ of the female students believed that women under the age of 18 years could not have a legal abortion; $40 \%$ of the men and $42 \%$ of the women believed that a married woman needed her husband's permission in order to have a legal abortion; and $67 \%$ of the men and $46 \%$ of the women believed that parental consent was required in order for a woman under the age of 18 years to have a legal abortion.

\section{Research methods and design Research design}

A cross-sectional survey design was used in this study. Sampling was multi-stage, namely stratified random sampling of schools and purposive sampling of grades in schools. In terms of stratification, the population in this study (the schools in the Buffalo City Municipality) was divided into five subpopulations. It is widely acknowledged that the Apartheid legacy of racialised schooling persists in post-Apartheid South Africa, with those schools most disadvantaged by the system of segregated schooling and Bantu Education continuing to struggle in terms of the delivery of quality education (Spreen \& Vally 2010). We thus sampled five types of schools: private schools; former
Model C schools (under Apartheid these were designated for white learners); former Department of Education and Training (DET) schools urban (formerly designated for black African learners in townships); former DET schools rural (formerly designated for black African learners in the former Bantustans); and the former House of Representatives (HOR) schools (formerly designated for 'coloured ${ }^{1}$ learners). Former House of Delegates schools (formerly designated for Indian learners) were not used in the stratified sampling because of the demographics of Buffalo City (a low percentage of the population is Indian people). Two schools were selected randomly within each of these subpopulations. Grade 11 learners in each of the schools were purposively decided upon as these learners would be somewhat older, possibly sexually active and therefore possibly more knowledgeable than younger learners. Grade 12 learners were excluded because of examination pressures. Grade 11 learners, typically, are in their 11th year of schooling.

A total of 514 learners agreed to take part in the study (with parental consent), as illustrated in Table 1 . The number of female respondents is double the number of male respondents, with the highest number of the respondents being in DET rural and urban schools. The higher proportion of female respondents is partially because of the fact that, according to the school registers, there are more female than male learners enrolled in Grade 11. That is to say, from all the schools that participated in this study (except in the pilot study) there are 606 registered female learners and 449 registered male learners in Grade 11. Furthermore, participation was voluntary; thus some male learners may have felt that abortion is a 'girl issue', serving to skew representation toward female learners.

\section{Data collection}

The data were collected by means of self-administered questionnaires in group situations. The meaning of each item was expanded upon by the second author, who oversaw the data collection, prior to the administration. The questionnaire used was constructed by the researchers and contained items on abortion and emergency contraception. The sections relevant to this article drew off the stipulations of the Act and are contained in Appendix 1. A funnel sequence was used in which questions went from the general to the specific. In the stipulations section, actual stipulations in the Act (e.g. that minors may have abortions) are counterbalanced by reverse statements of the stipulations (e.g. parental consent

1.The term 'Coloured' is used instead of Mixed race. The authors described the term as more historically accurate.

TABLE 1: Number of Grade 11 learners that participated in the study.

\begin{tabular}{|c|c|c|c|c|c|c|c|c|c|c|c|}
\hline \multirow[t]{2}{*}{ Type of school } & \multicolumn{2}{|c|}{ Private school } & \multicolumn{2}{|c|}{ HOR } & \multicolumn{2}{|c|}{ Model 'C' } & \multicolumn{2}{|c|}{ DET-rural } & \multicolumn{2}{|c|}{ DET-urban } & \multirow[t]{2}{*}{ Total } \\
\hline & A & B & $C$ & $\mathrm{D}$ & $E$ & $\mathrm{~F}$ & $\mathrm{G}$ & $\mathrm{H}$ & 1 & $J$ & \\
\hline No of Gr. 11 men & 1 & 42 & 11 & 7 & 3 & 14 & 12 & 38 & 14 & 28 & 170 \\
\hline No. of Gr. 11 women & 2 & 36 & 29 & 42 & 13 & 34 & 27 & 62 & 43 & 55 & 343 \\
\hline Non-responses & - & 1 & - & - & - & - & - & - & - & - & 1 \\
\hline Total & \multicolumn{2}{|c|}{81} & \multicolumn{2}{|c|}{89} & \multicolumn{2}{|c|}{64} & \multicolumn{2}{|c|}{139} & \multicolumn{2}{|c|}{140} & 514 \\
\hline
\end{tabular}

HOR, House of Representatives; DET, Department of Education and Training; Gr., Grade. 
is required) and by incorrect statement of stipulations that do not appear in the Act (e.g. only married women may have a legal abortion). The entire questionnaire took 15-20 minutes to complete.

The questionnaire was translated into Afrikaans and isiXhosa as these, in addition to English, are the dominant languages in Buffalo City. To check for variation and to ensure that no meaning was lost in the translation process, back-translation by two independent language specialists was used. Learners could choose which version they preferred to answer. The questionnaire was piloted before the finalised version in the study was administered.

\section{Data analysis}

Non-responses were given a code and were included in the data analysis. After cleaning, data were analysed using descriptive statistics to organise, summarise and present a general overview of the data. Chi-square and crosstabulations were used to examine relationships between the sex of the learners, the schools they attended, stated sexual activity in the previous 12 months and the various knowledge variables.

\section{Context of the study}

Grade 11 learners are typically between the ages of 15 and 20 years. This disparity can be ascribed to the inequalities in access to education, amongst other services. High levels of poverty in former homelands and townships has meant that former DET schools are characterised by high rates of repetition, dropout, late entry and re-entry, meaning that many grades contain older learners (Panday et al. 2009). This is evident in Table 2 where it can be seen that the average and median ages of Grade 11 learner respondents in the DET-rural and DET-urban schools are higher than the other schools and the age range is wider (the learners were asked to give their ages in years only).

Table 3 is a representation of the number of respondents who claim to have engaged in sexual activity in the previous 12 months and those who claim they have not, with the split being approximately $50 / 50$. The proportion that claimed to have been sexually active in the previous 12 months varied, depending on the type of school. It is noted that there is also a possibility of learners not being honest about their sexual activity.

\section{Results}

Not a single respondent could name the Choice of Termination of Pregnancy Act correctly. Over half $(55.06 \% ; n=284$ of the respondents stated explicitly that they did not know the name of the legislation and $21.40 \%(n=110)$ did not respond. Only $8.56 \%(n=44)$ of the responses included the 'termination of pregnancy' component of the wording. Over half $(54.67 \%$; $n=281$ ) of the respondents did not know the year in which the Act was passed and $22.96 \%(n=118)$ did not respond. Only $4.85 \%(n=25)$ knew that the legislation was passed in the mid-1990s.

Table 4 outlines respondents' responses to the item on the circumstances under which abortion may be legally performed in South Africa. A minority $(42.22 \%$; $n=217$ ) of the respondents had accurate knowledge regarding the circumstances under which abortion may be performed. Over half of the respondents $(57.78 \% ; n=297)$ indicated that

TABLE 2: Age of respondents.

\begin{tabular}{lllll}
\hline Type of school & Private school & Model 'C' & HOR & DET-rural \\
\hline Age range (years) & $15-20$ & $16-19$ & $15-20$ & $15-23$ \\
Average age (years) & 17.27 & 16.96 & 17.11 & 18.10 \\
Median age (years) & 17 & 17 & 17 & 18.89 \\
\hline
\end{tabular}

HOR, House of Representatives; DET, Department of Education and Training.

TABLE 3: Respondents' sexual activity in the previous 12 months.

\begin{tabular}{llllll}
\hline Type of school & Private school & Model 'C' & HOR & DET-rural & DET-urban \\
\hline $\begin{array}{l}\text { Have been sexually active in the } \\
\text { last } 12 \text { months }\end{array}$ & $56(69.14 \%)$ & $36(55.38 \%)$ & $38(42.70 \%)$ & $50(35.97 \%)$ & Total \\
$\begin{array}{l}\text { Have not been sexually active } \\
\text { in the last } 12 \text { months }\end{array}$ & $25(30.86 \%)$ & $29(44.62 \%)$ & $51(57.30 \%)$ & $89(64.03 \%)$ & $62(44.29 \%)$ \\
\hline
\end{tabular}

HOR, House of Representatives; DET, Department of Education and Training.

TABLE 4: Responses to circumstances under which abortion may be performed legally in South Africa.

\begin{tabular}{|c|c|c|}
\hline Category & Total $[n]$ & Percentage \\
\hline Illegal: Abortion is illegal in South Africa under all circumstances. & 60 & 11.67 \\
\hline Rape, incest or sexual abuse: Abortion may be performed legally ONLY in cases of rape, incest or sexual abuse- & 75 & 14.59 \\
\hline $\begin{array}{l}\text { Physical or mental harm: Abortion may be performed legally ONLY in cases of potential physical or mental harm to the } \\
\text { woman or foetus. }\end{array}$ & 26 & 5.06 \\
\hline $\begin{array}{l}\text { Sexual violence and physical or mental harm: Abortion may be performed legally in cases of rape, incest or sexual abuse } \\
\text { AND in cases of potential physical or mental harm to the woman or foetus. }\end{array}$ & 99 & 19.26 \\
\hline Upon request: Abortion may be performed legally upon request of the woman up to a certain date of pregnancy. & 217 & 42.22 \\
\hline Total & 514 & 100 \\
\hline
\end{tabular}


abortion may be obtained under restrictive conditions or not at all, or did not respond. Just over $10 \%(n=60)$ thought that abortion is illegal under all circumstances.

In terms of stipulations within the Act, a minority of the respondents (42.41\%; $n=217$ ) had accurate knowledge regarding the gestation period under which abortion can be obtained; only half $(50 \% ; n=257)$ of the respondents knew that minors could obtain an abortion; and only $25.1 \%$ $(n=129)$ knew that parental consent is not required in order for a minor to terminate a pregnancy. Half the respondents (50.39\%; $n=259)$ knew that TOP clinics are obliged to provide pre-termination of pregnancy counselling to the woman, whilst only $39.49 \%(n=203)$ of the respondents knew that TOP clinics are obliged to provide voluntary posttermination of pregnancy counselling. Only 33.46\% $(n=172)$ knew that it is an offence to prevent a woman from obtaining a legal termination of pregnancy. Only $46.11 \%(n=237)$ knew that TOP clinics have been designated by the state for the provision of legal abortions. Just under two-thirds of the respondents $(64.01 \% ; n=329)$ knew that abortion is provided free of charge at government TOP clinics.

Reponses to the 'incorrect information' items showed some misunderstandings concerning the provision of abortion. Whilst $67.7 \%(n=348)$ responded in the negative to the question of whether only married women could obtain a legal abortion, just under a third (32.3\%; $n=166)$ responded 'yes', were 'not sure' or did not respond. Only $22.57 \%(n=116)$ responded in the negative when asked whether a married woman requires her husband's consent to obtain a legal abortion. Just over half $(51.36 \% ; n=264)$ responded positively and the rest were 'not sure' or did not respond. Just under half $(45.58 \% ; n=224)$ thought that TOP clinics were obliged to offer pre-termination of pregnancy counselling to the woman's partner, whilst 31.91\% $(n=164)$ thought that clinics were obliged to provide post-termination of pregnancy counselling to the woman's partner. A large minority $(44.55 \% ; n=229)$ thought that nurses are required to insist that the partner accompany the woman to the TOP clinic.
Table 5 outlines the relationships between respondents' sexual activity in the previous 12 months and their knowledge concerning the Act and its stipulations. For the most part, there is no significant relationship between claimed sexual activity and knowledge of the Act and its stipulations. Significant relationships existed in items concerning parental consent, spousal consent and provision of pre-termination of pregnancy counselling to the woman. Cross-tabulation revealed that: more of the non-sexuallyactive respondents were unsure regarding parental consent than the sexually active respondents; more sexually-active respondents knew that spousal consent is not required for a married woman to have a legal abortion and more of the nonsexually-active respondents were unsure regarding spousal consent; and sexually-active respondents were more likely to be unsure concerning the provision of pre-termination of pregnancy counselling to the woman than non-sexuallyactive respondents.

Table 6 outlines data concerning relationships between sex and knowledge regarding the Act and its stipulations. Once again, on most items there were no significant differences. Where there were significant differences, cross-tabulation revealed that: a higher proportion of male $(58.24 . \% ; n=99)$ compared with female respondents $(45.77 \% ; n=157)$ knew that minors are allowed to have a legal abortion; more women $(46.06 \% ; n=158)$ than men $(35.29 \% ; n=61)$ thought that abortion could be requested up to 12 weeks of pregnancy or were not sure; a higher proportion of male $(54.12 \% ; n=92)$ compared with female learners $(38.19 \% ; n=131)$ indicated that TOP clinics are obliged to provide the woman's partner with pre-termination of pregnancy counselling; and a higher percentage of female $(24.49 \% ; n=84)$ compared with male learners $(17.06 \% ; n=29)$ knew that nurses do not insist on the woman's partner accompanying her to the TOP clinic.

Table 7 demonstrates the relationship between schools and the knowledge regarding the Act and its stipulations. It is in relation to this variable that the most differences between the learners emerged. Significant differences emerged in more items in this variable than non-significant differences.

TABLE 5: Relationship between respondents' sexual activity and various items on knowledge of the Choice on Termination of Pregnancy Act and its stipulations. 
There is a significant relationship between schools and the knowledge regarding the circumstances under which legal abortion is allowed, as is illustrated in Table 8. In other words, the respondent's school plays a role in the knowledge that the respondent has concerning the circumstances under which legal abortion can be obtained. This is illustrated by the higher proportion of respondents from private, Model $\mathrm{C}$ and HOR schools who knew that abortion is available upon request up to a certain gestation period and the lower proportion of respondents from these schools who thought that it is illegal, compared with the lower proportion of respondents from both DET-rural and DET-urban schools who know that abortion is legal on request and the higher proportion who thought that it is illegal.

With regard to the various stipulations of the Act, crosstabulations revealed the following in terms of the items in which significant differences were found: higher percentages of respondents from DET-rural and DET-urban schools thought that minors are not allowed to have abortions or were unsure about this stipulation; DET-rural schools had the lowest proportion of respondents who knew that parental consent is not needed for minors to have a legal abortion and the highest proportion who thought that parental consent is

TABLE 6: Relationship between sex of the respondents and various items on knowledge of the Choice on Termination of Pregnancy Act and its stipulations.

\begin{tabular}{|c|c|}
\hline Knowledge on sex & Chi-square \\
\hline Knowledge regarding circumstances under which abortion can be obtained legally in South Africa. & $X^{2}(16, N=476)=4.64, p=0.326$ \\
\hline Knowledge regarding minors being allowed to obtain abortion. & $X^{2}(8, N=498)=8.99, p=0.011^{*}$ \\
\hline Knowledge regarding the requirement for parental consent. & $X^{2}(8, N=490)=4.19, p=0.123$ \\
\hline Knowledge regarding married women being able to have legal abortion. & $X^{2}(8, N=484)=5.55, p=0.062$ \\
\hline Knowledge regarding the requirement for spousal consent. & $X^{2}(8, N=496)=3.83, p=0.147$ \\
\hline Knowledge regarding gestation under which abortion may be obtained upon request. & $X^{2}(8, N=492)=8.92, p=0.012^{*}$ \\
\hline Knowledge regarding gestation under which abortion may be performed under certain specified conditions. & $X^{2}(8, N=492)=1.11, p=0.547$ \\
\hline Knowledge regarding the provision of voluntary pre-termination of pregnancy counselling to the woman. & $X^{2}(8, N=486)=5.40, p=0.067$ \\
\hline Knowledge regarding the provision of voluntary post-termination of pregnancy counselling to the woman. & $X^{2}(8, N=477)=0.074, p=0.964$ \\
\hline Knowledge regarding the provision of voluntary pre-termination of pregnancy counselling to the woman's partner. & $X^{2}(8, N=486)=11.12, p=0.004^{* *}$ \\
\hline Knowledge regarding the provision of voluntary post-termination of pregnancy counselling to the woman's partner. & $X^{2}(8, N=482)=0.776, p=0.678$ \\
\hline Knowledge regarding the prevention of a woman from obtaining a legal abortion. & $X^{2}(8, N=482)=1.31, p=0.518$ \\
\hline Knowledge regarding the state designating various sites as legal Termination of Pregnancy clinics. & $X^{2}(8, N=486)=5.54, p=0.063$ \\
\hline Knowledge regarding abortion being obtained for free at government Termination of Pregnancy Clinics. & $X^{2}(8, N=488)=5.88, p=0.053$ \\
\hline
\end{tabular}

$*$, indicate

TABLE 7: Relationship between schools and various items on knowledge of the Choice on Termination of Pregnancy Act and its stipulations.

Knowledge on school

Chi-square

Knowledge regarding circumstances under which abortion can be obtained legally in South Africa.

$X^{2}(16, N=477)=52.27, p=0.000^{*}$

Knowledge regarding minors being allowed to obtain abortion.

Knowledge regarding the requirement for parental consent.

$X^{2}(8, N=499)=17.82, p=0.022^{*}$

Knowledge regarding married women being able to have legal abortion.

Knowledge regarding the requirement for spousal consent.

Knowledge regarding gestation under which abortion may be obtained upon request.

Knowledge regarding gestation under which abortion may be performed under certain specified conditions.

Knowledge regarding the provision of voluntary pre-termination of pregnancy counselling to the woman.

Knowledge regarding the provision of voluntary post-termination of pregnancy counselling to the woman.

Knowledge regarding the provision of voluntary per-termination of pregnancy counselling to the woman's partner.

Knowledge regarding the provision of voluntary post-termination of pregnancy counselling to the woman's partner.

Knowledge regarding the prevention of a woman from obtaining a legal abortion.

Knowledge regarding the state designating various sites as legal Termination of Pregnancy clinics.

Knowledge regarding abortion being obtained for free at government Termination of Pregnancy Clinics.

Knowledge regarding nurses insisting on the partner accompanying the woman to the Termination of Pregnancy clinic.

$X^{2}(8, N=491)=23.09, p=0.003 * *$

$X^{2}(8, N=485)=14.64, p=0.066$

$X^{2}(8, N=497)=45.29, p=0.000 * *$

$X^{2}(8, N=493)=19.60, p=0.011 *$

$X^{2}(8, N=493)=8.07, p=0.426$

$X^{2}(8, N=487)=47.00, p=0.000 * *$

$X^{2}(8, N=477)=22.50, p=0.004^{* *}$

$X^{2}(8, N=487)=10.45, p=0.234$

$X^{2}(8, N=482)=0.12 .16, p=0.144$

$X^{2}(8, N=483)=8.55, p=0.382$

$X^{2}(8, N=487)=20.32, p=0.009 * *$

$X^{2}(8, N=489)=3.22, p=0.919$

$X^{2}(8, N=483)=21.99, p=0.005^{* *}$

*, indicates significant relationship at the 0.05 level

$*^{* *}$, indicates significant relationship at the 0.01 level

TABLE 8: Cross-tabulation: Schools and knowledge of circumstances under which legal abortion is allowed.

\begin{tabular}{lllllll}
\hline Schools & Illegal (\%) & $\begin{array}{l}\text { Rape, incest or } \\
\text { sexual abuse (\%) }\end{array}$ & $\begin{array}{l}\text { Physical or } \\
\text { mental harm (\%) }\end{array}$ & $\begin{array}{l}\text { Sexual violence and } \\
\text { physical or mental } \\
\text { harm (\%) }\end{array}$ & $\begin{array}{l}\text { Upon } \\
\text { request (\%) }\end{array}$ \\
\hline HOR & 4.49 & 8.99 & 2.25 & 26.97 & 51.69 & $\begin{array}{l}\text { Missing } \\
\text { responses (\%) }\end{array}$ \\
DET-rural & 14.39 & 12.23 & 6.47 & 17.99 & 41.73 & 5.62 \\
DET-urban & 17.86 & 20.71 & 3.57 & 22.86 & 22.86 & 1.19 \\
Private & 9.88 & 9.88 & 6.17 & 13.58 & 55.56 & 12.14 \\
Model C & 4.62 & 20.00 & 7.69 & 10.77 & 55.38 & 100 \\
\hline
\end{tabular}

HOR, House of Representatives; DET, Department of Education and Training. 
required; DET-rural and DET-urban schools had the highest percentage of respondents who thought that spousal consent was required in order for a married woman to obtain a legal termination of pregnancy; a higher proportion of respondents from DET-urban, DET-rural and private schools were not sure if abortion was obtainable up to 12 weeks of pregnancy versus a higher proportion of respondents from DET-urban and DET-rural schools who thought that abortions are not obtainable until up to 12 weeks; more DET-rural and DETurban respondents thought that TOP clinics are not obliged to provide voluntary pre-termination and post-termination of pregnancy counselling to the woman; DET-rural and DETurban schools had the highest percentage of respondents who thought that the state had not designated sites as legal TOP clinics, but a higher percentage of HOR, private and Model C school respondents indicated that they were unsure of this stipulation; and DET-rural and DET-urban schools had the lowest proportion of respondents who knew that nurses do not insist on a partner accompanying the woman to a TOP clinic.

\section{Discussion}

The fact that none of the respondents had accurate knowledge about the name of the Act or when it was passed could be seen as insignificant. It is entirely possible to know about the conditions under which abortion is legal without knowing the name of the Act or when it was passed. However, learners' knowledge of these conditions was also poor. Half or less than half were able to indicate accurately the circumstances under which abortion may be performed (viz. on request up to a certain date of gestation), or the various stipulations of the Act (viz. the gestation date for requesting an abortion; that minors may request abortions, that parental consent is not required for a minor to request an abortion; that TOP clinics are obliged to provide voluntary pre- and post-TOP counselling; that it is an offense to prevent a woman from obtaining a legal TOP). The exception was knowledge about abortion being provided free of charge, which just under two-thirds of the respondents knew. This lack of knowledge supports the views of Ratlabala et al.'s (2007) participants who indicated that young people are uninformed regarding the Act.

Some worrying misunderstandings were also evident. Only one-fifth knew that married women do not need their husbands' permission for a TOP, whilst a substantial minority thought that clinics were obliged to provide pre- and postTOP counselling to the woman's partner and that nurses had to insist on partners accompanying the woman to the clinic. Research shows that young people have misconceptions not only with regard to TOP, but also in other areas of reproductive health (Oni et al. 2005)

This kind of lack of knowledge and the misconceptions potentially have severe implications in terms of a young woman's decision making regarding the outcome of her pregnancy. David and Lee (2002:10) defined informed choice or consent as (1) access to sufficient information, (2) understanding the information, (3) competence to evaluate potential consequences, (4) freedom to make a choice, and (5) the ability to make and express that choice'. If, as suggested, a woman's ability to make an informed reproductive decision rests on, firstly, access to sufficient information and, secondly, understanding that information, there is cause for concern. Whilst adequate information is not a sufficient condition for the exercise of reproductive rights, it certainly is a necessary condition. Furthermore, the misconceptions evident in the data (e.g. that men have more of a say in the termination of a pregnancy than the Act stipulates; and that minors require parental consent) may further impede young women in accessing a termination of pregnancy.

As found in other research, the lack of knowledge and misconceptions were not evenly distributed. Although the sex of the learners and their stated sexual activity in the previous 12 months had little effect on their knowledge, there was a significant relationship between many of the knowledge items and the school a learner attends. The former DET school learners fared the worst on most items. We cannot, however, simply ascribe this to the schools or the sexuality and/or reproduction education that these schools provide. A complex range of factors to do with location and access to information resources such as television, radio, newspaper, internet, social media via cell phones, as well as the education provided in the schools, could account for the differences in knowledge between schools. What is clear, however, is that the same pattern of reproductive rights inequities that have appeared in other research and that tend to centre on race and class are also evident in this research.

\section{Ethical considerations}

Ethical clearance for the study was obtained from the Research Projects and Ethics Review Committee of the Psychology Department of Rhodes University (2009/11).

\section{Potential benefits and hazards}

Despite abortion potentially being a sensitive topic, the questionnaire was considered low risk in that it asked respondents for factual information only. The respondents did not have to provide information on personal opinions or experiences. At the end of the research, factual information on the CTOP stipulations were provided to the learners.

\section{Recruitment procedures}

Permission to conduct the study was gained from the Eastern Cape Department of Education and from the principals of the schools. The aims and procedures of the study were explained in detail to the parents by means of a letter and the parents were asked to sign if they consented to their child participating in the study. The respondents were provided with a similar cover letter as well as a verbal explanation from the second author. Respondents were also informed that their participation was voluntary. Thus, they were free to leave the administration venue if and when they felt uncomfortable. 


\section{Informed consent}

Parents and respondents were informed that: data collection would not disrupt the respondents' learning; the name of the school and the names of the respondents would not appear in the raw data or in any publication; participation was entirely voluntary and should respondents feel uncomfortable during the data collection, they were free to leave or not answer the questions. Only learners whose parents had signed the consent forms and who signed the consent forms themselves were allowed to participate in the study.

\section{Data protection}

Data were entered into a password-protected file. Raw data forms were stored for a year and then destroyed.

\section{Reliability and validity Reliability}

The reliability of the research was increased through a number of devices. Firstly, the questionnaire had, for the most part, uniform questions and fixed responses; secondly, it was presented in three languages, which minimised any confusion that would have arisen as a result of language barriers; thirdly, there was a rigorous back-translation procedure; and, finally, the questionnaires were selfadministered, thereby avoiding researcher influence.

\section{Validity}

Content validity was aided through the use of actual stipulations from the Act and a pilot study in which ambiguous or problematic questions were highlighted and corrected. The questionnaire was also scrutinised by two researchers in the Psychology Department.

\section{Limitations}

Non-responses to questions were a limitation in this study. It was not known whether these non-responses were because the respondents did not understand the questions or because they did not know the answer. The non-responses did not apply consistently to particular questions, but were distributed across the questionnaire. In addition, this study was only conducted in Buffalo City Municipality and is thus not necessarily generalisable to other parts of South Africa.

\section{Recommendations}

In a country in which stigma and a range of subtle discourses concerning abortion (Macleod, Sigcau \& Luwaca 2011) potentially serve as barriers to women accessing abortion, it is imperative that at least the most fundamental aspect of reproductive rights, namely, the right to information, is not undermined. Where such information is lacking, it is likely that young women, when faced with an unwanted pregnancy, will utilise the services of illegal abortion providers. The possibility of morbidity as a result of unsafe abortion and the resultant fall-out, not only for the young woman but for her family and for the health system, mean that the provision of information is vital.

Concerted efforts on the part of the Departments of Health and Basic Education to provide such basic information as the contents of the Act and where termination of pregnancy may be accessed to young people are essential. This information should be included in the Life Orientation learning area at schools. All educators, but particularly school counsellors, should be able to communicate accurate knowledge to the learners on request. The Department of Health should have an ongoing multimedia campaign in which this basic information is disseminated via radio, newspaper, pamphlets, and television. Posters containing this information should be on display at all public health facilities and all health service providers should be able to provide accurate information on request.

\section{Conclusion}

The preamble to the Act (1996) recognises 'that both women and men have the right to be informed of and to have access to safe, effective, affordable and acceptable methods of fertility regulation of their choice...' [emphasis added]. The results of this survey show that young people are being denied their right to be informed about the stipulations of the Act. Learners were often unsure of broader issues concerning abortion (e.g. its legal status) as well as specifics (e.g. who may access abortion and how access works). Knowledge varied according to the type of school, with the type of school probably forming a proxy for location and class.

There may be multiple reasons for learners' lack of knowledge and misconceptions. Ratlabala et al.'s (2007) participants indicated that it was because of a lack of coordination amongst health professionals and educators in the dissemination of information. This may well be the case, given the negative attitudes of many nurses to sex and contraceptive use amongst teenagers (Wood \& Jewkes 2006); the resistance of nurses to having any involvement in abortion or even providing information in this regard (Jewkes, Gumede et al. 2005); and the fact the Life Orientation manuals refer to abortion, where indeed it is featured, as something to be regretted (Macleod 2009). It is also possible, however, that the lack of knowledge is, at least partially, a result of insufficient public health dissemination through multimedia sources.

\section{Acknowledgements}

This research was funded by the National Research Foundation. We thank the Eastern Cape Department of Education and the principals of the schools for permission to conduct the study. We thank the teachers for facilitating our access to learners and the learners, themselves, for their time in completing the questionnaire.

\section{Competing interests}

The authors declare that they have no competing financial or personal relationship(s) which may have inappropriately influenced them in writing this article. 


\section{Authors' contributions}

C.M. (Rhodes University) was the project leader and sourced project funding; she conceptualised the project, supervised data collection and analysis and wrote the bulk of the article. L.S. (Rhodes University) helped conceptualise the project; she collected and analysed the data and contributed to the article write-up. G.S. (Rhodes University) assisted with project conceptualisation and data analysis; he acted as the statistical consultant on the project and contributed to article write-up.

\section{References}

Buchmann, E.J., Mensah, K. \& Pillay, P., 2002, 'Legal termination of pregnancy among teenagers and older women in Soweto, 1999-2001', South African Medical Journal 92(9), 729-731.

Cooper, D., Dickson, K., Blanchard, K., Cullingworth, K., Mavimbela, N., Von Mollendorf C. et al., 2005, 'Medical abortion: The possibilities for introduction in the public sector in South Africa', Reproductive Health Matters 13(26), 35-43. http://dx.doi. org/10.1016/S0968-8080(05)26203-1

Cooper, D., Dickson, K., Blanchard, K., Cullingworth, K., Mavimbela, N., Von Mollendorf Spreen, C.A. \& Vally, S., 2010, 'Prospects and pitfalls: A review of post-apartheid Spreen, C.A. \& Vally, S., 2010, 'Prospects and pitfalls: A review of post-apartheid
education policy research and analysis in South Africa', Comparative Education 46(4), 429-448. http://dx.doi.org/10.1080/03050068.2010.519478

David, H.P. \& Lee E., 2002, 'Abortion and its health effects', in J. Worell (ed.), Encyclopedia of Women and Gender, pp. 1-14, Academic Press, San Diego.

Department of Health, 2002, South Africa Demographic and Health Survey 1998, Full Report, Department of Health, Pretoria.

Jewkes, R., Rees, H., Dickson, K., Heather, B. \& Levin, J., 2005, 'The impact of age on the epidemiology of incomplete abortions in South Africa after legislative change', BJOG: An International Journal of Obstetrics and Gynaecology 112(3), 355-359. http://dx.doi.org/10.1111/j.1471-0528.2004.00422.x

Jewkes, R.K., Gumede, T., Westaway, M.S., Dickson, K., Brown, H. \& Rees, H., 2005 'Why are women still aborting outside designated facilities in metropolitan South Africa?' BJOG: An International Journal of Obstetrics \& Gynaecology 112(9), 12361242. http://dx.doi.org/10.1111/j.1471-0528.2005.00697.x

Klugman, B. \& Varkey, S., 2001, 'From policy development to policy implementation: The South African Choice on Termination of Pregnancy Act', in B. Klugman \& D. Budlender (eds.), Advocating for abortion access: Eleven country studies, pp. 251-282, The Women's Health Project, Johannesburg.
Macleod, C., 2008, 'Developing principles for research about young women and abortion: a feminist analysis of difficulties in current South African studies', Feminist Africa 11, 55-72.

Macleod, C., 2009, 'Danger and disease in sex education: the saturation of 'adolescence' with colonialist assumptions', Journal of Health Management 11(2), 375-389. http://dx.doi.org/10.1177/097206340901100207

Macleod, C., Sigcau, N. \& Luwaca, P., 2011, 'Culture as a discursive resource opposing legal abortion', Critical Public Health 21(2), 237-245. http://dx.doi.org/10.1080/ 09581596.2010.492211

Makiwane, M., Udjo, E., Richter, L. \& Desmond, C., 2006, 'Is the child support grant associated with an increase in teenage fertility in South Africa? Evidence from national surveys and administrative data', HSRC, Pretoria.

Mbele, A.M., Snyman, L. \& Pattinson, R.C., 2007, 'Impact of the Choice on Termination of Pregnancy Act on maternal morbidity and mortality in the west of Pretoria', South African Medical Journal 96(11), 1196-1198.

Moodley, J. \& Akinsooto, V.S., 2003, 'Unsafe abortions in a developing country: has liberalisation of laws on abortions made a difference?', African Journal of Reproductive Health 7(2), 34-38. http://dx.doi.org/10.2307/3583211

Morroni, C., Myer, L. \& Tibazarwa, K., 2006, 'Knowledge of the abortion legislation among South African women: A cross-sectional study', BMC Reproductive Health 3, 7. http://dx.doi.org/10.1186/1742-4755-3-7

Mwaba, K. \& Naidoo, P., 2006, 'Knowledge, beliefs and attitudes regarding abortion in South Africa among a sample of university students', Journal of Psychology in Africa 16(1), 53-58.

Oni, T.E., Prinsloo, E.A.M., Nortje, J.D. \& Joubert, G., 2005, 'High school students' attitudes, practices and knowledge of contraception in Jozini, KwaZulu-Natal', South African Family Practice 47(6), 54-57.

Panday, S., Makiwane, M., Ranchord, C. \& Letsoala, T., 2009, 'Teenage pregnancy in South Africa - with a specific focus on school-going learners', Child, Youth, Family and Social Development, Human Sciences Research Council, Department of Education, Pretoria.

Ratlabala, M.E., Makofane, M.D. \& Jali, M.N., 2007, 'Perceptions of adolescents in low resourced areas towards pregnancy and the Choice of Termination of Pregnancy (CTOP)', Curationis 30(1), 26-31. http://dx.doi.org/10.4102/curationis.v30i1.1041

South Africa, 1975, Abortion and Sterilisation Act, No. 2 of 1975, Government Gazette, Section 3, 478, Government Printers, Pretoria.

South Africa, 1996, Choice on Termination of Pregnancy (CTOP) Act, No. 92 of 1996 Government Gazette, Section 2, 45, Government Printers, Pretoria.

South Africa, 2008, Choice on Termination of Pregnancy Amendment Act, 2008, No. 1 of 2008, Government Gazette, Vol. 512, No. 213, Government Printers, Pretoria.

Wood, K. \& Jewkes, R., 2006, 'Blood blockages and scolding nurses: barriers to adolescent contraceptive use in South Africa', Reproductive Health Matters 14(27), 109-118. http://dx.doi.org/10.1016/S0968-8080(06)27231-8 


\section{Appendix 1}

Relevant sections of the questionnaire - knowledge of the Choice on Termination of Pregnancy Act and its stipulations.

1. The legislation dealing with abortion in South Africa is called:

2. The Choice on Termination of Pregnancy Act was passed in

Knowledge of the Choice on Termination of Pregnancy Act

Question 1: Choose one of the following.

\begin{tabular}{|l|l|}
\hline Abortion is illegal in South Africa under all circumstances & $\checkmark$ \\
\hline $\begin{array}{l}\text { 1.1. Abortion may be legally performed ONLY in cases of rape, incest } \\
\text { or sexual abuse }\end{array}$ & \\
\hline $\begin{array}{l}\text { 1.2. Abortion may be legally performed ONLY in cases of potential } \\
\text { physical or mental harm to the woman or foetus }\end{array}$ & \\
\hline $\begin{array}{l}\text { 1.3. Abortion may be legally performed in cases of rape, incest or } \\
\text { sexual abuse AND in cases of potential physical or mental harm to } \\
\text { the woman or foetus }\end{array}$ & \\
\hline $\begin{array}{l}\text { 1.4. Abortion may be legally performed upon request of the woman up } \\
\text { to a certain date of pregnancy }\end{array}$ & \\
\hline
\end{tabular}

Question 2: Please tick only one option for each of the following questions.

\begin{tabular}{|c|c|c|c|}
\hline According to the legislation concerning abortion & Yes & No & Not sure \\
\hline $\begin{array}{l}\text { 2.1. Women under the age of } 18 \text { years are allowed to } \\
\text { have an abortion. }\end{array}$ & & & \\
\hline $\begin{array}{l}\text { 2.2. Parental consent is needed for a woman under the } \\
\text { age of } 18 \text { years to have a legal abortion. }\end{array}$ & & & \\
\hline 2.3. Only a married woman can have a legal abortion. & & & \\
\hline $\begin{array}{l}\text { 2.4. If a married woman wants an abortion legally, she } \\
\text { must have her husband's permission. }\end{array}$ & & & \\
\hline $\begin{array}{l}\text { 2.5. A legal termination of pregnancy can be obtained } \\
\text { upon request up to } 12 \text { weeks of pregnancy. }\end{array}$ & & & \\
\hline $\begin{array}{l}\text { 2.6. After } 12 \text { weeks, abortion may occur only under } \\
\text { certain specified conditions. }\end{array}$ & & & \\
\hline $\begin{array}{l}\text { 2.7. Termination of pregnancy clinics are obliged to } \\
\text { provide voluntary pre-termination of pregnancy } \\
\text { counselling to the woman. }\end{array}$ & & & \\
\hline $\begin{array}{l}\text { 2.8. Termination of pregnancy clinics are obliged to } \\
\text { provide voluntary post-termination of pregnancy } \\
\text { counselling to the woman. }\end{array}$ & & & \\
\hline $\begin{array}{l}\text { 2.9. Pre-termination of pregnancy counselling must be } \\
\text { offered to the woman's partner at the Termination } \\
\text { of Pregnancy clinic. }\end{array}$ & & & \\
\hline $\begin{array}{l}\text { 2.10. Post-termination of pregnancy counselling must be } \\
\text { offered to the woman's partner at the Termination } \\
\text { of Pregnancy clinic. }\end{array}$ & & & \\
\hline $\begin{array}{l}\text { 2.11. Preventing a woman from obtaining a legal } \\
\text { termination of pregnancy is an offence. }\end{array}$ & & & \\
\hline $\begin{array}{l}\text { 2.12. The state has designated (chosen) various sites as } \\
\text { legal Termination of Pregnancy clinics. }\end{array}$ & & & \\
\hline $\begin{array}{l}\text { 2.13. Abortion may be obtained free of charge at } \\
\text { government Termination of Pregnancy clinics. }\end{array}$ & & & \\
\hline $\begin{array}{l}\text { 2.14. Nurses must insist on the partner accompanying the } \\
\text { woman to the Termination of Pregnancy clinic. }\end{array}$ & & & \\
\hline
\end{tabular}

